\title{
The effects of mite parasitism on the reproduction and survival of the Taiwan field mice (Apodemus semotus)
}

\author{
Jhan-Wei Lin ${ }^{1}$, Hsuan-Yi Lo' ${ }^{1}$ Hsi-Chieh Wang ${ }^{2}$ and Pei-Jen Lee Shaner ${ }^{1 *}$
}

\begin{abstract}
Background: The effects of parasitism on host survival and reproduction can be highly complex depending on the type of parasites, host sex and life-history characteristics, and ecological conditions. In this study, we tested sex-biased parasitism from Trombiculid mites (Acarina: Trombiculidae) and their sex-specific effects on host reproduction and survival, in a natural population of the Taiwan field mouse (Apodemus semotus). We performed surveys of A. semotus and their Trombiculid mites between April 2010 and August 2011 and again between June and September 2012 in a subtropical evergreen forest in Taiwan.

Results: Contrary to the commonly reported male-biased parasitism in mammals, we did not find sex-biased parasitism in A. semotus. We found that mite abundance was negatively associated with A. semotus reproduction and survival in both males and females. The mite abundance and rodent reproduction fluctuated seasonally, and the peak reproductive season coincided with the time period of relatively low mite abundance.

Conclusions: Trombiculid mites could potentially regulate A. semotus populations through reducing their reproduction and survival. The overlapping periods of peak reproduction and low parasitism implied that $A$. semotus may adjust their reproductive phenology to avoid periods of high parasitism or be constrained by parasites to reproduce only during periods of low parasitism. Although our results are correlational, host breeding season has been shown to increase in response to experimental reduction of parasitism. We suggest that parasites may shape host reproduction phenology through which they may influence host population dynamics.
\end{abstract}

Keywords: Ectoparasite; Host parasite; Life history; Rodent; Sex-biased parasitism; Trombiculidae

\section{Background}

Parasites can alter host physiology (Schall et al. 1982; Simon et al. 2004), body condition (Hakkarainen et al. 2007; Vandegrift et al. 2008; Turner et al. 2012), behavior (Schall et al. 1982; Goodman and Johnson 2011), social dominance (Schall and Houle 1992; Zohar and Holmes 1998), and life history (Schall 1983; Schall and Dearing 1987; Shields and Wood 1993; Merino and Potti 1995; Lochmiller and Deerenberg 2000; Skarstein et al. 2001; Chadwick and Little 2005; Cox and John-Alder 2007; Kallio et al. 2007), leading to complex ecological and evolutionary consequences in host populations (Hamilton and Zuk 1982; Buckling and

\footnotetext{
* Correspondence: pshaner@ntnu.edu.tw

${ }^{1}$ Department of Life Science, National Taiwan Normal University, No. 88, Sec. 4, Tingzhou Rd, Taipei 11677, Taiwan

Full list of author information is available at the end of the article
}

Rainey 2002; Chadwick and Little 2005). Theoretical and field studies suggest that parasites can regulate host populations, playing a role comparable to predators (May and Anderson 1979; Albon et al. 2002; Redpath et al. 2006; Lemaitre et al. 2009). Unlike predator-prey interactions where survival is arguably the single most important parameter to consider, parasites may affect host reproduction, survival, or the trade-off between the two (Sheldon and Verhulst 1996; Stien et al. 2002; Burns et al. 2005; Vandegrift et al. 2008; Lemaitre et al. 2009), making their role in host regulation an extremely dynamic phenomenon.

Reduction in host fecundity is commonly found in parasitic associations (Hurd 2001). For example, ectoparasite removal increased litter size in Columbian ground squirrels (Spermophilus columbianus) (Neuhaus 2003), as well as juvenile mass at emergence and their subsequent 
survival probabilities in North American red squirrels (Tamiasciurus hudsonicus) (Patterson et al. 2013). A similar effect was also found in endoparasites. Vandegrift et al. (2008) demonstrated that helminth parasites prevented the white-footed mouse (Peromyscus leucopus) from breeding in mid-summer. However, positive associations between parasitism and host fecundity that resulted from immunosuppression or behavioral change caused by sex hormone during breeding season were also reported (Schwanz 2008; Gooderham and Schulte-Hostedde 2011). A recent study on red squirrels ( $T$. hudsonicus) demonstrated that helminth parasites were negatively associated with reproductive success in both male and female squirrels whereas fleas and mites were positively associated with male reproductive success (Gooderham and Schulte-Hostedde 2011). Therefore, the relationship between parasitism and host reproduction may vary depending on the life histories of the host and parasite species.

Sex-biased parasitism is common in natural host populations (Poulin 1996; Zuk and McKean 1996; Schalk and Forbes 1997; Moore and Wilson 2002; Klein 2004; Morand et al. 2004; Cox and John-Alder 2007; Krasnov et al. 2012). Among vertebrates, parasitism risk is generally higher for males due to a presumed trade-off between sexual traits and parasite defense (Poulin 1996; Zuk and McKean 1996; Schalk and Forbes 1997; Morand et al. 2004) or behaviors that incur high infection rates (e.g. defending territories, aggression; Brown et al. 1994). Nevertheless, female-biased parasitism and lack of sex-biased parasitism in small mammals have also been reported (Morales-Montor et al. 2004; Christe et al. 2007; Sanchez et al. 2011). In species for which nutritional needs during reproduction compromise mothers' immunity (Klein and Roberts 2010) or encourage mothers to engage in behaviors with increased infection risks (e.g. feeding at contaminated food patches, overlapping with others' home ranges; Sanchez et al. 2011), the trade-off between reproduction and parasite defense can be stronger for females or becomes equal between the sexes. In addition to sex-biased parasitism, parasitism effects on hosts could also be sex-specific (Vandegrift et al. 2008; Gooderham and Schulte-Hostedde 2011; Bordes et al. 2012). For example, helminth removal increased breeding only in female P. leucopus and survival only in the males (Vandegrift et al. 2008). Therefore, more empirical evidence is needed to fully understand the causes and consequences of sex-biased parasitism and sex-specific parasitism effects in natural populations (Krasnov et al. 2005; Bordes et al. 2012).

Recent meta-analyses reported a latitudinal gradient in parasite-induced mortality, with parasite virulence and associated host mortality increasing toward lower latitudes (Møller et al. 2009; Robar et al. 2010). However, ecological studies of parasitism in subtropical/tropical regions remain relatively rare (Waller 1997). In this study, we examined sex-biased parasitism from Trombiculid mites (Acarina: Trombiculidae) and their sex-specific effects on host reproduction and survival, in a natural population of the Taiwan field mouse (Apodemus semotus) in a subtropical forest. Trombiculid mites, a main vector of Orientia tsutsugamushi that causes scrub typhus in human, are parasitic at larval stage and can be found on a wide range of vertebrate hosts including birds, mammals, and lizards (Nelson et al. 1975). Trombiculid larvae (chiggers) attach to a host where the skin is thin for feeding, which usually lasts several days to a few weeks (Wharton and Fuller 1952; Baker et al. 1956). Free-living stage of Trombiculid mites are soil dwellers with complex life cycles (reviewed by Shatrov and Kudryashova 2006). Although seasonal patterns of mite development are still unclear, available reports suggest that these mites could retard their development at any stage in the cold period (e.g. temperature $<10^{\circ} \mathrm{C}$; Takahashi et al. 1993). In the tropics, these mites may continue their development without any conspicuous diapause and have a much shortened life cycle (reviewed by Shatrov and Kudryashova 2006). For example, under laboratory conditions (i.e., $27^{\circ} \mathrm{C}$ and relatively humidity of $85 \%$ ), the entire life cycle of Trombiculid mites can be completed in 2 to 3 months (Traub and Wisseman 1968), as appose to 150 to 400 days among boreal species (Shatrov and Kudryashova 2006). Therefore, seasonality in their larval emergence and abundance is likely influenced by the climate of the study system. Apodemus is the most common rodent in forests of the Palaearctic region with over 20 species (Corbet 1978; Corbet and Hill 1992), many of which are known hosts to Trombiculid mites (Ree et al. 1992; Xing-Yuan et al. 2007). Therefore, the 'Apodemus-Trombiculid mites' association provides an ideal system to study parasite effects on host.

Using an observational data set, we asked the following questions: (1) Is mite parasitism sex-biased? (2) Is mite parasitism related to host body mass? (3) Is mite parasitism associated with host survival and reproduction? (4) Do the associations in (3) sex-specific?

\section{Methods}

\section{The study system}

The study was conducted in an evergreen forest (Pinus-Alnus-Quercus) in the Shei-Pa National Park $\left(121^{\circ} 18^{\prime} \mathrm{E}, 24^{\circ} 21^{\prime} \mathrm{N}\right.$; elevation $\left.c .1,800 \mathrm{~m}\right)$. The climate at the study site can be grouped into three seasons, the warm and moist spring (March through June, mean temperature: $14^{\circ} \mathrm{C}$, relative humidity: $88 \%$, precipitation: $835 \mathrm{~mm}$ ), the warm and wet summer (July through October: mean temperature: $16^{\circ} \mathrm{C}$, relative humidity: $87 \%$, precipitation: 2,059 $\mathrm{mm}$ ), and the cool and dry winter (November through February, mean temperature: $9^{\circ} \mathrm{C}$, 
relative humidity: $85 \%$, precipitation: $387 \mathrm{~mm}$ ) (2005 to 2008 weather data, Taiwan Forestry Bureau). The information on mite taxonomy is scarce for this geographic region. However, we identified two genera of Trombiculid mites, Leptotrombidium spp. and Walchia spp., which use A. semotus as hosts.

\section{Mice trapping}

The trapping was performed from April 2010 to August 2011 (the 2010 to 2011 survey) and again from June to September 2012 (the 2012 survey). During the 2010 to 2011 survey, we established three trapping grids, each comprising 64 stations arranged in an $8 \times 8$ array $(10 \mathrm{~m}$ between stations). The distance between adjacent grids was c. $60 \mathrm{~m}$ apart. This distance was chosen based on the average distance moved by adult $A$. semotus between two successive days (c. 17 to $34 \mathrm{~m}$ ) and their average home range size (c. 1,267 to $3,270 \mathrm{~m}^{2}$, equivalent to 36 to $57 \mathrm{~m}$ in radius) reported in Lin and Shiraishi (1992a). One live trap was set up at each trapping station in the evening (192 traps per night across the three grids), baited with sweet potato, mixed seeds, and peanut butter, and checked the next morning. A total of nine trapping sessions were performed (April, June, August, October, and December 2010 and February, April, June, and August 2011), each comprising three consecutive days. During the 2012 survey, we established one trapping grid at the same site, comprising 36 stations arranged in a $6 \times 6$ array (10 $\mathrm{m}$ between stations). Two live traps were set up at each trapping station in the evening (72 traps per night), baited with sweet potato, mixed seeds, and peanut butter, and checked the next morning. A total of four monthly trapping sessions from June to September were performed. Due to weather constraints, we performed the trapping for five consecutive days in June and September, but only for three consecutive days in July and August.

Upon capture, each rodent was marked with an ear tag (National Band and Tag Co., Newport, KY, USA; during the 2010 to 2011 survey) or a radio-frequency identification chip (Watron Technology Corp., Hsinchu, Taiwan; during the 2012 survey), sexed, and weighted. Their physical signs of reproduction were also recorded, including descended testicles in males, pregnancy, lactation, and perforated vagina in females. For males, descended testicles indicate that they are reproductively capable, whereas for females, pregnancy and lactation indicate breeding, and perforated vagina indicates mating. Therefore, these physical signs are more direct indicators of reproduction in females than in males. The mice were immediately released after processing at the station where they were captured. All procedures in mice trapping and sampling were approved by the National Taiwan Normal University's Animal Care and Use Committee (protocol no. 102004).

\section{Rodent survival}

The lifespan of $A$. semotus in the wild is approximately 1 year. At the current study site, we had previously reported that only $1 \%$ to $10 \%$ of the individuals were recaptured beyond 2 months (based on data from August 2010 to June 2011 and from May to September 2013; Shaner et al. 2013). Therefore, we estimated rodent survival as the probability of surviving a 2-month period using the Cormack-Jolly-Seber (CJS) model (White and Burnham 1999). The CJS model estimates apparent survival $(\phi)$ and recapture probability (p). Apparent survival is the probability that an individual had survived a given time period and did not emigrate out of the study area, and recapture probability is the probability that an individual had survived a given time period and was recaptured at the next trapping period. One advantage of the CJS model is that survival and recapture probabilities can be simultaneously estimated as functions of individual covariates (e.g. parasite abundance on a rodent). If parasites affect host activity, individuals with different parasite abundances may have different recapture probabilities, potentially confounding the effect of parasites on host survival. By incorporating parasite abundance as an individual covariate for $\phi$ and/or $p$, we can control for parasite effect on host recapture probability while evaluating their effect on host survival.

A large capture-recapture dataset is often needed to parameterize the CJS model. Given the small sample size in the 2012 survey, we limited survival estimates to the 2010 to 2011 dataset. We first explored four model structures: constant $\phi$ and p, constant $\phi$ and sex-specific $p$, sex-specific $\phi$ and constant $p$, and sex-specific $\phi$ and p. However, only the models of constant $\phi$ and $p$, and sex-specific $\phi$ and constant $\mathrm{p}$, can be fully parameterized. Therefore, we used the following CJS model structure to test the effect of mite parasitism on rodent survival and recapture probability:

$$
\begin{aligned}
& \varphi_{\text {female }}=\text { int }_{\text {female }}+\beta_{\text {female }} \text { xmite abundance } \\
& \varphi_{\text {male }}=\text { int }_{\text {male }}+\beta_{\text {male }} \text { xmite abundance } \\
& p=\text { int }_{p}+\beta_{p} \text { xmite abundance }
\end{aligned}
$$

where $\beta_{\text {female }}$ and $\beta_{\text {male }}$ are female- and male-specific slope of mite abundance for the survival function, and int $_{\text {female }}$ and int $t_{\text {male }}$ are female- and male-specific intercept for the survival function. When $\beta_{\text {female }}=\beta_{\text {male }}$ and int $_{\text {female }}=$ int $_{\text {male }}$, the model of sex-specific $\phi$ reduces to constant $\phi . \beta_{\mathrm{p}}$ and int $\mathrm{p}_{\mathrm{p}}$ are the slope and intercept for the recapture probability function. Mite abundance is based on the number of mites found on each individual, grouped into four levels: '0' (zero mite), ' 1 ' (1 to 9 mites), '2' (10 to 19 mites), and '3' (20 mites or more) (see 'Mite 
infection and abundance' below). For repeatedly captured individuals, the mean level of mite abundance is used.

\section{Mite infection and abundance}

Mite data were collected between December 2010 and August 2011 (the last five trapping session in the 2010 to 2011 survey) and again between June and September 2012 (all four trapping sessions in the 2012 survey). During the 2010 to 2011 survey, we temporarily restrained each rodent by hand to inspect the mites attached to the ears (Additional file 1: Figure S1) and the skin area around the genital region. We grouped the number of mites found on each individual into one of the four levels: '0' (zero mite), ' 1 ' ( 1 to 9 mites), '2' (10 to 19 mites), and '3' (20 mites or more). The lowest level of zero mite found indicates uninfected animals (mite infection $=0$ ), whereas the other three levels indicate infected animals (mite infection $=1$ ). Although this method only provides an ordinal measure of mite abundance, it does not require placing the animals under anesthesia, for which we did not have adequate logistic support at the time. During the 2012 survey, however, we were able to perform anesthesia (2\% to 4\% isoflurane administered through a gas anesthesia system with a nose cone, AN-10 T, Singa Technology Corp., Taipei, Taiwan) to obtain a complete count of the mites. The 2012 data set indicates that the mite counts were positively correlated with the four levels of mite abundance $(r=0.57 ; P=0.0007 ; \mathrm{n}=32$; Additional file 1 : Figure S1). Furthermore, $91 \%$ of the mice in the 2012 data set had a mite count between 0 to 29 (0 mite, 1 to 9 mites, 10 to 19 mites, 20 to 29 mites; Additional file 1: Figure S1), suggesting that the four abundance levels can effectively capture most of the variation in mite count with limited data lumping.

\section{Statistical analyses}

The nine trapping sessions for which we had parasitism data were grouped into three seasons according to the climate at the site: spring (April and June 2011, June 2012), summer (August 2011, July, August, and September 2012), and winter (December 2010 and February 2011). We tested the effects of sex, season, and their interactions on mite parasitism using the generalized linear mixed model (GLMM). The response variable is mite infection $(0 / 1)$ or mite abundance (zero mite, 1 to 9 mites, 10 to 19 mites, 20 mites or more). When testing mite infection, we applied binomial distribution with logit link function; when testing mite abundance, we applied Poisson distribution with log link function. The survey year, trapping grid, and individual identity were included as random factors to account for spatial-temporal heterogeneity and nonindependence of repeated records from the same individuals. Although none of the mice were captured in both years, ten individuals (5\% of the 214 unique individuals) were observed on more than one grid. We assigned different grid codes to these cross-grid individuals (e.g. the three mice that were observed on both grids $\mathrm{A}$ and $B$ were assigned 'AB' as their grid value). To check if the effects of sex, season, and their interactions on mite abundance are sensitive to our four-level grouping of mite abundance, we also performed GLMM on mite counts (Poisson distribution) using only the 2012 data. Because only one trapping grid was used in 2012, we dropped trapping grid and survey year from the random factors (individual identity was kept as a random factor). We tested the effects of sex, season, reproduction, mite abundance, and their interactions on A. semotus body mass using GLMM (normal distribution). We tested the effects of sex, season, mite abundance, and their interactions on $A$. semotus reproduction using GLMM (binomial distribution). For the body mass and reproduction models, we included trapping grid, survey year, and individual identity as random factors. To reach model convergence for the reproduction analysis, we reduced the four levels of mite abundance to 3 ( 0 to 9 mites, 10 to 19 mites, 20 or more mites). Type I errors for post hoc comparisons following the GLMMs were Tukey-Kramer adjusted. To test parasitism effect on $A$. semotus survival, we obtained the $95 \%$ confidence limits of the slopes of mite abundance on survival $(\phi)$ from the CJS model. An upper 95\% confidence limit smaller than zero indicates a negative association between mite abundance and rodent survival whereas a lower 95\% confidence limit greater than zero indicates a positive association. All statistical analyses were performed in SAS 9.3.

\section{Results}

Reproduction phenology and population abundance of the host

The long-term phenology of $A$. semotus reproduction was based on 617 reproduction records from 407 unique adults (148 females and 259 males) during the 2010 to 2011 survey and 25 unique adults (12 females and 13 males) during the 2012 survey. The difference in sample size between these two surveys was due to different levels of trapping effort. After the number of mice captured is standardized by trapping effort (i.e., the number of unique mice captured per 100 trap $\times$ night), $A$. semotus population abundance appeared to be quite stable across seasons and years with less than 2.5-fold difference between the maximum in October 2010 and the minimum in September 2012 (Figure 1). The percentage of reproductively active adults (reproductively capable males and reproducing females) was higher in spring (0.57, 0.54, and 0.63 across years; April and June combined) and lower in winter (0.14 for year 2010 to 2011; December and February combined; Figure 1). The reproduction in summer fluctuated from year to year 

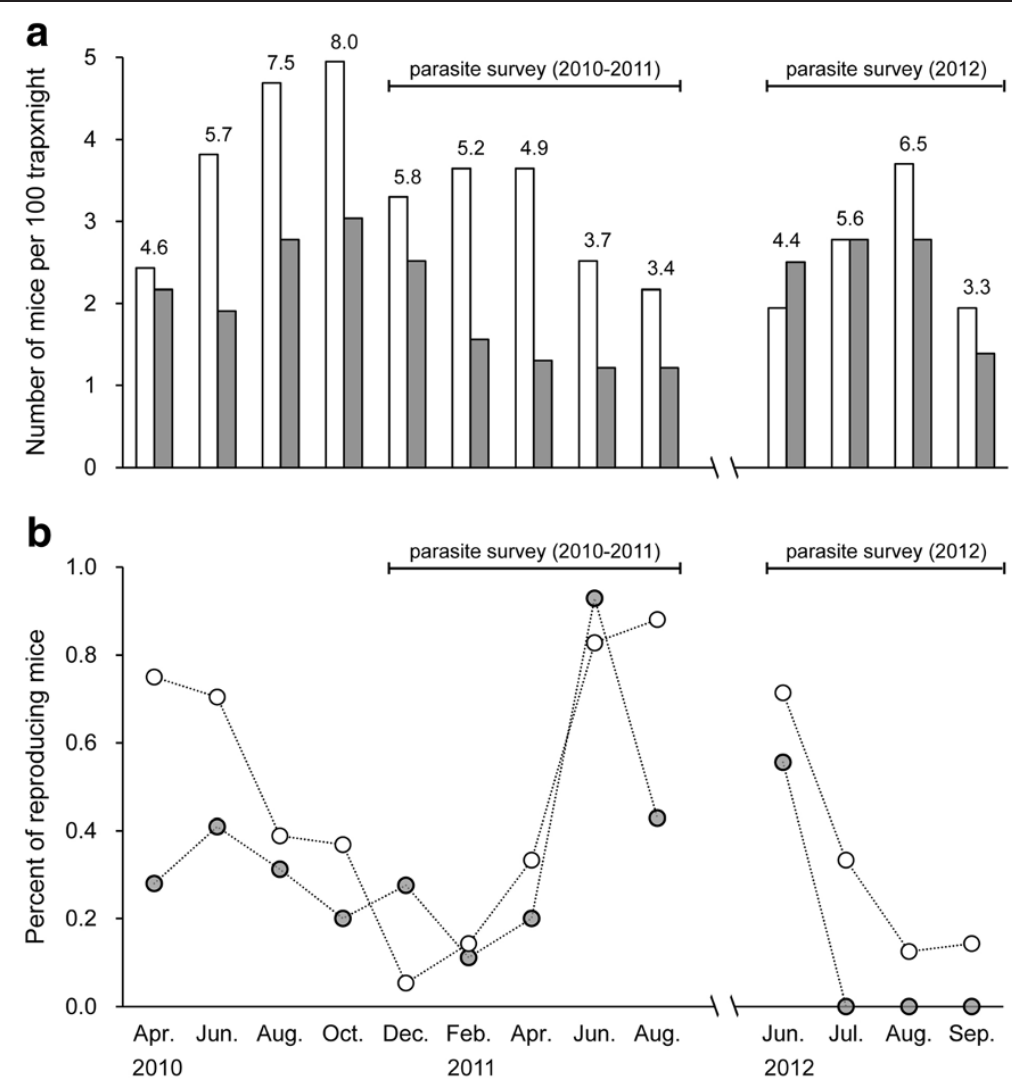

Figure 1 Seasonal pattern in Apodemus semotus abundance and reproduction. (a) The abundance of $A$. semotus is represented by the numbers of unique male (unfilled bars) and female (filled bars) A. semotus captured in each trapping session, which are standardized (number of mice per 100 trap $\times$ night). The text above each bar denotes the total number of mice captured per 100 trap $\times$ night, males and females combined. (b) The circles denote the percentages of males (unfilled circles) and females (filled circles) with signs of reproduction in each trapping session. Signs of reproduction are: descended testicles in males, pregnancy, lactation, and perforated vagina in females. Parasite investigation began in December 2010, which is divided into the 2010 to 2011 survey (December 2010 through August 2011) and the 2012 survey (June through September 2012).

(0.33, 0.72, and 0.11 across years; July through October; Figure 1).

\section{Sex and seasonal difference in mite parasitism}

We obtained 291 records of mite parasitism from 214 unique adults (78 females and 136 males), both survey years combined. In the 2012 survey, we obtained 32 records of mite count data from 25 unique adults (12 females and 13 males). Mite infection was common for both sexes across seasons (0.70 to 0.94; Figure 2a). The mite abundance ranged from 1.2 to 1.7 across seasons and between the sexes (Figure 2b), which fell within the category of 10 to 19 mites. Neither mite infection nor mite abundance was sex biased, but they tended to vary among seasons (Table 1). Specifically, the probability of mite infection was $c .10 \%$ higher in winter $(0.93 \pm 0.04 \mathrm{SE})$ than in spring $(0.79 \pm 0.08)$ and summer $(0.83 \pm 0.09$; Figure 2a). A marginal season effect also existed for mite abundance (Table 1), with a non-significant trend of higher mite abundance in winter $(1.6 \pm 0.2)$ than in spring $(1.3 \pm 0.2)$ and summer $(1.2 \pm 0.2$; Figure $2 b)$. The analysis of mite count data from the 2012 survey revealed a similar pattern of seasonal variation with little sex difference (sex: $F_{1,5}=0.19, P=0.68$; season: $F_{1,5}=59.71$, $P=0.0006$; sex $\times$ season: $\left.F_{1,5}=1.67, P=0.25\right)$. The mite counts were significantly higher in summer (July through September: $13.7 \pm 3.5$ ) than in spring (June: $2.2 \pm 0.6$ ) for the 2012 survey (there were no winter trapping during this year).

Data on host body mass and reproduction state were available for all 291 records of mite parasitism from 214 unique adults (78 females and 136 males). Of these 214 adults, we obtained capture-recapture histories from 189 unique individuals (66 females and 123 males) from the 2010 to 2011 survey for survival estimates.

The male $A$. semotus were heavier than the females (male: $25.6 \pm 0.5 \mathrm{~g}$; female: $23.8 \pm 0.5 \mathrm{~g}$; Table 2). Both reproductively capable males and reproducing females were heavier than non-reproducing mice (reproducing: $26.7 \pm 0.5$ g; non-reproducing: $22.7 \pm 0.5$ g; Table 2). 


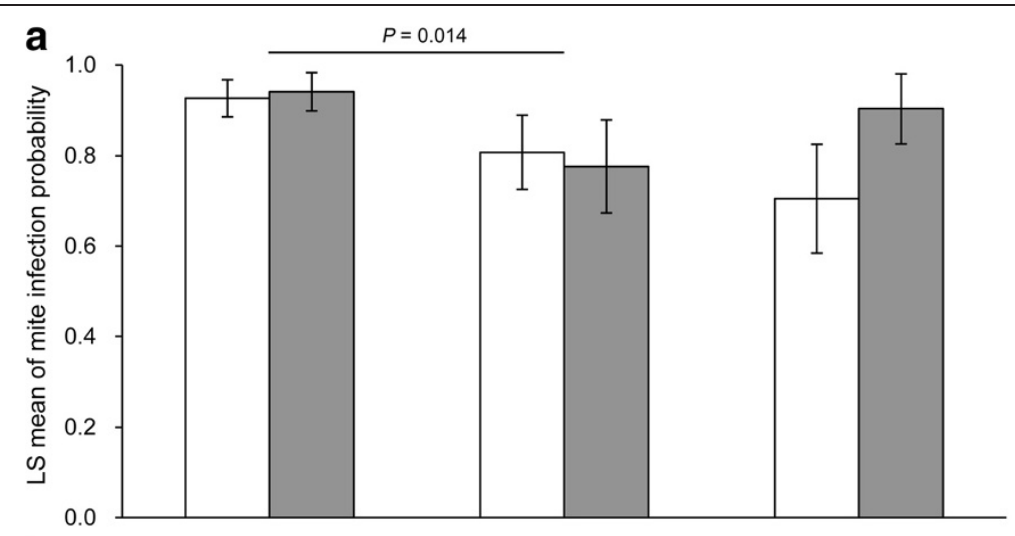

b

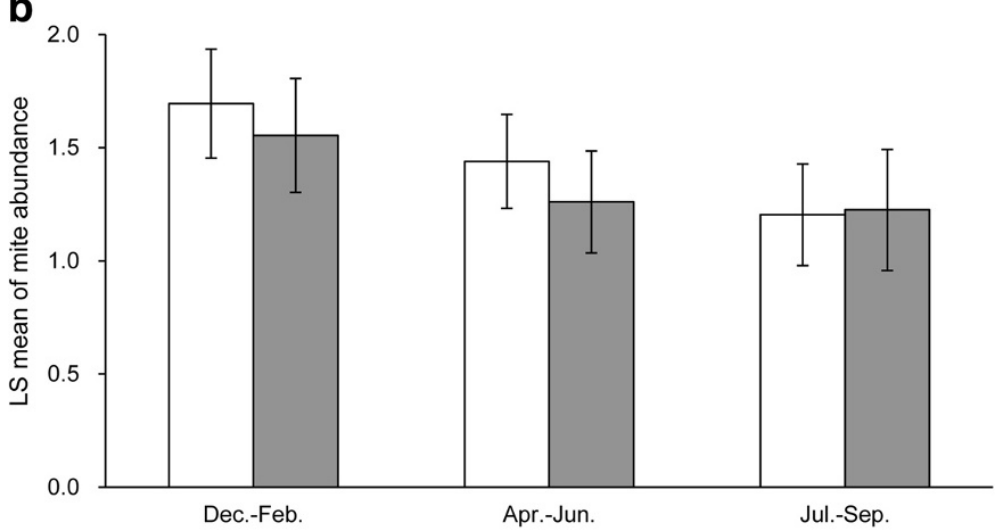

Figure 2 Infection and abundance of Trombiculid mites in Apodemus semotus. The least-square means of (a) infection probability and (b) abundance level are estimated for males (unfilled bars) and females (filled bars) separately for each season (spring: April to June, summer: July to October, winter: December to February). The mite abundance is quantified at four levels ( $0=$ zero mites, $1=1$ to 9 mites, $2=10$ to 19 mites, and $3=20$ mites or more). The error bars denote $1 \mathrm{SE}$. A significant difference in mite parasitism between seasons in pair-wise comparisons (both sexes combined) is indicated with the Tukey-Kramer adjusted $P$ value and a horizontal line connecting the two seasons.

Consequently, A. semotus body mass was higher in spring $(25.5 \pm 0.5 \mathrm{~g})$ and summer $(26.0 \pm 0.6 \mathrm{~g})$ when there were more reproducing adults than in winter $(22.6 \pm 0.5 \mathrm{~g}$; Table 2). Nevertheless, A. semotus body mass was not associated with mite abundance (Table 2 (See Table 1.)), suggesting that any potential effect of mite parasitism on the mice was not likely mediated through host body mass.

\section{Table 1 The generalized linear mixed model of the infection and abundance of Trombiculid mites in Apodemus semotus}

\begin{tabular}{|c|c|c|c|c|c|c|}
\hline \multirow[t]{2}{*}{ Effect } & \multirow{2}{*}{$\begin{array}{l}\text { Num } \\
\text { DF }\end{array}$} & \multirow{2}{*}{$\begin{array}{l}\text { Den } \\
\text { DF }\end{array}$} & \multicolumn{2}{|c|}{ Mite infection } & \multicolumn{2}{|c|}{ Mite abundance } \\
\hline & & & $F$ & $P$ & $F$ & $P$ \\
\hline Sex & 1 & 73 & 1.23 & 0.27 & 0.38 & 0.54 \\
\hline Season & 2 & 73 & 4.24 & 0.02 & 2.46 & 0.09 \\
\hline Sex $\times$ season & 2 & 73 & 1.19 & 0.31 & 0.13 & 0.88 \\
\hline
\end{tabular}

The mite infection is whether or not an individual was infected with mites; the mite abundance is categorized into four levels (zero mite, 1 to 9 mites, 10 to 19 mites, and 20 mites or more). The seasons are spring (April and June 2011, June 2012), summer (August 2011, July, August, and September 2012), and winter (December 2010 and February 2011). Significant results are in italics.

\section{Host body mass, reproduction, and survival}

Mite abundance had a negative association with $A$. semotus reproduction for both females and males (Table 3 and Figure 3). The estimated probability of reproduction for a mouse infected with 20 mites or more was only 0.14 , compared to $>0.4$ for a less-infected individual (Figure 3). Although $A$. semotus reproduction was seasonal, the negative association between parasitism and reproduction was consistent across seasons (non-significant parasitism $\times$ season interaction; Table 3).

The upper 95\% confidence limit of the slope of mite abundance for the survival function of male A. semotus was smaller than zero (Table 4), indicating a negative association between mite abundance and male survival. A similar trend also existed for females (Table 4). In fact, when we reduced the model from sex-specific survival to constant survival by forcing $\beta_{\text {female }}=\beta_{\text {male }}$ and int $_{\text {female }}=$ int $_{\text {male, }}$ the Akaike information criterion $\left(\mathrm{AIC}_{\mathrm{c}}\right)$ decreased, resulting in a 6-fold improvement in model likelihood (Table 4). This suggests that the males and females shared a similar, negative association between mite abundance and survival (Figure 4). Even though the recapture probability 
Table 2 The generalized linear mixed model of Apodemus semotus body mass

\begin{tabular}{|c|c|c|c|c|}
\hline Effect & Num DF & Den DF & $F$ & $P$ \\
\hline$\overline{\text { Sex }}$ & 1 & 43 & 4.99 & 0.03 \\
\hline Season & 2 & 43 & 4.13 & 0.02 \\
\hline Reproduction & 1 & 43 & 40.27 & $<.0001$ \\
\hline Mite abundance & 3 & 43 & 0.96 & 0.42 \\
\hline Sex $\times$ season & 2 & 43 & 2.08 & 0.14 \\
\hline Sex $\times$ reproduction & 1 & 43 & 0.01 & 0.92 \\
\hline Sex $\times$ mite abundance & 3 & 43 & 0.98 & 0.41 \\
\hline Season $\times$ reproduction & 2 & 43 & 3.76 & 0.03 \\
\hline Season $\times$ mite abundance & 6 & 43 & 1.37 & 0.25 \\
\hline Reproduction $\times$ mite abundance & 3 & 43 & 0.91 & 0.44 \\
\hline Sex $\times$ season $\times$ reproduction & 2 & 43 & 0.24 & 0.78 \\
\hline Sex $\times$ season $\times$ mite abundance & 6 & 43 & 1.06 & 0.40 \\
\hline Sex $\times$ reproduction $\times$ mite abundance & 3 & 43 & 1.68 & 0.19 \\
\hline Season $\times$ reproduction $\times$ mite abundance & 5 & 43 & 1.16 & 0.34 \\
\hline Sex $\times$ season $\times$ reproduction $\times$ mite abundance & 2 & 43 & 1.62 & 0.21 \\
\hline
\end{tabular}

The mite abundance is categorized into four levels (zero mite, 1 to 9 mites, 10 to 19 mites, and 20 mites or more). The seasons are spring (April and June 2011 , June 2012), summer (August 2011, July, August, and September 2012), and winter (December 2010 and February 2011). The reproduction is whether a male has descended testicles or a female has perforated vagina and is pregnant or lactating. Significant results are in italics.

of $A$. semotus had broad confidence intervals, its lower $95 \%$ confidence limit was still greater than zero, indicating a positive association between recapture probability and mite abundance (Table 4). Therefore, the negative association between parasitism and host survival was not likely an artifact from reduced recapture probability among infected individuals.

\section{Discussion}

In this study, we showed that parasitism from Trombiculid mites was associated with reduced reproduction and survival in a wild rodent, $A$. semotus, suggesting a potential role of Trombiculid mites in regulating their host populations. This negative association was similar between male and female $A$. semotus. Furthermore, we did not find

Table 3 The generalized linear mixed model of Apodemus semotus reproduction

\begin{tabular}{lllll}
\hline Effect & Num DF & Den DF & $\boldsymbol{F}$ & $\boldsymbol{P}$ \\
\hline Sex & 1 & 65 & 1.81 & 0.18 \\
Season & 2 & 65 & 10.7 & $<.0001$ \\
Mite abundance & 2 & 65 & 5.19 & 0.008 \\
Sex $\times$ season & 2 & 65 & 6.71 & 0.002 \\
Sex $\times$ mite abundance & 2 & 65 & 0.93 & 0.40 \\
Season $\times$ mite abundance & 4 & 65 & 0.51 & 0.73 \\
\hline
\end{tabular}

The mite abundance is categorized into three levels ( 0 to 9 mites, 10 to 19 mites, and 20 mites or more). The seasons are spring (April and June 2011, June 2012), summer (August 2011, July, August, and September 2012), and winter (December 2010 and February 2011). Due to model convergence issue, the three-way interaction (sex $\times$ reproduction $\times$ mite abundance) is not included. Significant results are in italics. sex-biased parasitism in either breeding or non-breeding season. This is one of the few empirical studies on host-parasite ecology from a relatively under-studied geographic region (Southeast Asia), where warm and wet climates year-round may allow ectoparasites with free-living stages to breed more frequently and persist at high densities (Takahashi et al. 1993; Waller 1997; Shatrov and Kudryashova 2006).

Sex-biased parasitism is a complex phenomenon that can be influenced by the biology of particular host and parasite species, mediated by environmental factors, and exhibited spatial and temporal variation (reviewed by Krasnov et al. 2012). Although ectoparasites tend to show male-biased parasitism (Krasnov et al. 2012 and references therein), several ecological characteristics of Trombiculid mites and $A$. semotus may help explain the lack of sex-biased parasitism in this study. Trombiculid mites only remain attached to a host individual for a short period of time (several days to a few weeks; Wharton and Fuller 1952; Baker et al. 1956), and they appear to be tightly associated with particular habitats in which they are able to infect a wide range of host species (Shatrov and Kudryashova 2006), suggesting this parasite may not be choosy about host individuals. A recent study on Trombiculid mites (Leptotrombidium imphalum) in lowland Taiwan suggests that they are not able to freely distribute themselves according to the quality of host individuals, presumably due to their limited mobility (Kuo et al. 2011). Host sexual dimorphism in spacing behavior, immune defense, and/or body size can work synergistically or individually to drive sex-biased 


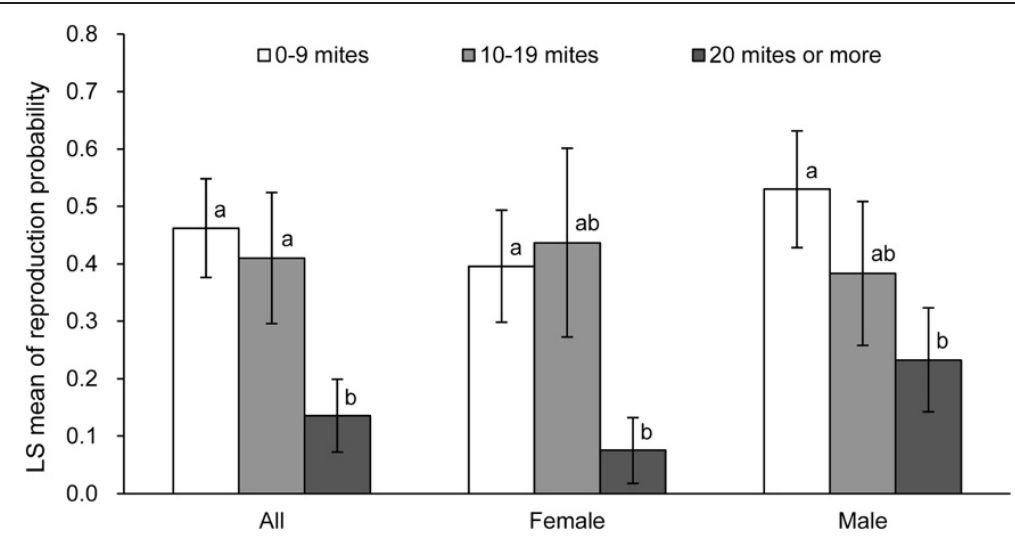

Figure 3 Probability of reproduction in Apodemus semotus as a function of mite abundance. All seasons (spring: April to June, summer: July to October, winter: December to February) are pooled. The males and females are estimated separately as well as combined. The reproduction is the probability of being reproductively capable in males (i.e., descended testicles) or mating/breeding in females (i.e., perforated vagina, pregnancy, lactation). The mite abundance is categorized into three levels (0 to 9 mites, 10 to 19 mites, and 20 mites or more) in order to reach model convergence. The error bars denote $1 \mathrm{SE}$. Different letters denote significant differences in the probability of reproduction.

parasitism. Although male A. semotus are larger than females, the difference in their body mass is less than $2 \mathrm{~g}$ (c. 7\% of the body mass). Furthermore, male and female A. semotus have similar home-range sizes, and their home ranges often overlap (Lin and Shiraishi 1992a). To the best of our knowledge, sexual dimorphism in immune defense in A. semotus has not been studied. However, studies on other rodents suggest that host gender may not have a systematic effect on their immune defense (Khokhlova et al. 2004; Waterman et al. 2014). Therefore, the ecology of $A$. semotus does not seem to support sex-biased parasitism.

If these mites have limited ability to select and switch between host individuals, their infection and abundance should be primarily determined by host spacing behavior. Following this argument, the negative association between mite parasitism and the survival and reproduction of $A$. semotus could be caused by different spacing behaviors in the host. For example, reproducing or long-lived mice may have smaller or more stable home ranges, reducing their encounter rates with the parasites. However, based on a study of $A$. semotus home ranges at a different site (Lin and Shiraishi 1992a), their length of capture history (a proxy for survival) was not correlated with their home range sizes. Unfortunately, the trapping protocol in the current study is spatially and temporally too sparse to determine their home ranges. Therefore, spacing behaviors of reproducing versus non-reproducing $A$. semotus, as well as A. semotus with different life-history strategies (long-lived versus short-lived), remained to be studied.

Although characteristics of host individuals, such as body mass and age, are frequently documented to influence patterns of parasitism, we did not find a relationship between mite abundance and host body mass, regardless of host sex, host reproductive state, or season. The lack of relationship between host body mass and mite parasitism, however, suggests that any potential parasitism effect on $A$. semotus survival or reproduction is not likely mediated through their body mass. On the other hand, if older hosts are more likely to reproduce yet less likely to be parasitized

Table 4 The Cormack-Jolly-Seber model of Apodemus semotus survival and recapture probability as functions of mite abundance

\begin{tabular}{|c|c|c|c|c|c|c|c|}
\hline \multirow[t]{2}{*}{ Model } & \multirow[t]{2}{*}{$\mathrm{AIC}_{\mathrm{c}}$} & \multirow{2}{*}{$\begin{array}{l}\text { AIC }_{c} \\
\text { weights }\end{array}$} & \multirow[t]{2}{*}{ Deviance } & \multicolumn{2}{|l|}{ Survival function } & \multicolumn{2}{|c|}{ Recapture probability function } \\
\hline & & & & int $_{\text {sex }}$ & $\beta_{\text {sex }}$ & int $_{p}$ & $\beta_{p}$ \\
\hline \multirow[t]{4}{*}{$\varphi($ sex $) p()}$. & 281.98 & 0.86 & 273.79 & Female: & Female: & $-1.50(-3.21,0.22)$ & $9.33(1.73,16.94)$ \\
\hline & & & & $0.42(-0.84,1.68)$ & $-0.73(-1.47,0.02)$ & & \\
\hline & & & & Male: & Male: & & \\
\hline & & & & $0.42(-0.39,1.22)$ & $-0.58(-1.01,-0.16)$ & & \\
\hline$\varphi() p.()$. & 285.53 & 0.14 & 273.14 & $0.39(-0.30,1.07)$ & $-0.61(-0.98,-0.24)$ & $-1.47(-3.20,0.25)$ & $9.31(1.70,12.92)$ \\
\hline
\end{tabular}

Only data from the 2010 to 2011 survey was used (189 unique individuals). The mite abundance is categorized into four levels (zero mite, 1 to 9 mites, 10 to 19 mites, and 20 mites or more). Mean mite abundance is used for repeatedly captured individuals. The logit link function is applied. The primary CJS model is $\varphi$ (sex) $\mathrm{p}($.$) , which has sex-specific survival functions \left(\varphi_{\text {female }}=\right.$ int $_{\text {female }}+\beta_{\text {female }} \times$ mite abundance, $\varphi_{\text {male }}=$ int $_{\text {male }}+\beta_{\text {male }} \times$ mite abundance $)$ and a recapture probability

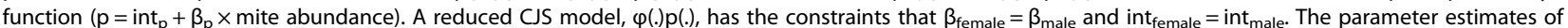
the survival and recapture probability functions are expressed as the means followed by their $95 \%$ confidence limits in parentheses. 


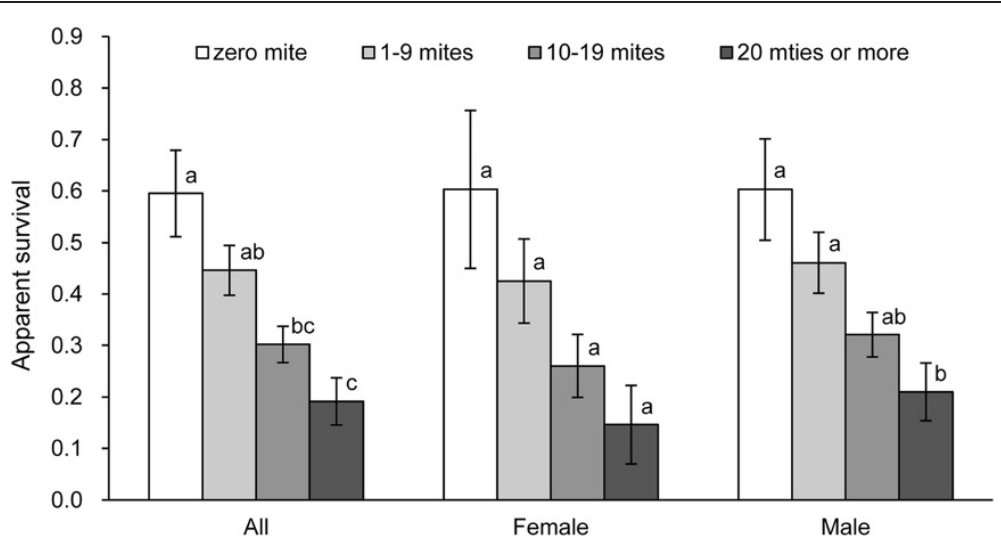

Figure 4 Apparent survival of Apodemus semotus as a function of mite abundance. All trapping sessions (December 2010, February, April, June, and August 2011) are pooled. The males and females are estimated separately as well as combined. The apparent survival is the probability that an individual survived a 2-month period and remained at the study site. The mite abundance is categorized into four levels (0 mite, 1 to 9 mites, 10 to 19 mites, and 20 mites or more. The error bars denote 1 SE. Different letters denote significant differences in apparent survival.

(either because of their lower quality as hosts or their more effective parasite defense), the negative association between mite parasitism and $A$. semotus reproduction could reflect an age effect. Although majority of the mice in this study were only captured once, we were able to examine 36 individuals (24 males and 12 females) that were known to have survived at least 4 months as adults from the 2010 to 2011 survey (adults are usually more than 1 month old; Lin and Shiraishi 1992b; PLS, personal observation). We did not find an age effect on individuals' probability of reproduction for either sex (Additional file 1: Table S1). In fact, one adult male with eight consecutive recaptures spanning a total period of 14 months (June 2010 to August 2011) showed a reproduction record of 11001011 , illustrating that their reproduction is quite flexible and may be adjusted according to individual and environmental conditions.

Parasitism from Trombiculid larvae has been reported to vary seasonally (Klukowski 2004; Dietsch 2005). Seasonality in parasitic infection can be explained by parasite-related and/or host-related traits. Under laboratory conditions (i.e., $27^{\circ} \mathrm{C}$ and relatively humidity of $85 \%$ ), the entire life cycle of Trombiculid mites can be completed in 2 to 3 months (Traub and Wisseman 1968). Our study site is in a subtropical montane forest with warm and humid climate year-round, which may help explain the high prevalence of mite parasitism across seasons (0.70 to 0.94; Figure 2a). Against the high background level of mite prevalence, we also found seasonal variation in their prevalence and abundance. Interestingly, the season of lower mite abundance coincided with peak reproductive season for the host, suggesting A. semotus might be adjusting their reproduction phenology to avoid parasitism, or they might be constrained to reproduce during periods of low parasitism. Although this off-set in timing between host reproduction and increased parasitism risk could be coincidental, we know of at least one study that experimentally demonstrated it. Vandegrift et al. (2008) showed that another rodent host, $P$. leucopus, was able to extend their breeding season to mid-summer when their helminth parasites were experimentally reduced. In fact, many host-related traits (e.g. territoriality, immunocompetence, hormone) and their physiological trade-offs have been shown to vary between breeding and non-breeding seasons (reviewed by Krasnov et al. 2005; Martin et al. 2008), contributing to seasonal fluctuation in parasitism. Rodent species have been reported to invest less in immune defense if probability and/or intensity of parasite attack is low and vice versa (Khokhlova et al. 2004; de Bellocq et al. 2006). Consequently, if immune defense is costly for $A$. semotus, which is a likely scenario considering the consistently high prevalence of mite parasitism they are facing (Khokhlova et al. 2004; de Bellocq et al. 2006), it would be more advantageous, or it would be only possible, for these mice to breed during periods of low probability and/or intensity of parasitism.

During this study, we were able to record the presence of ticks (Ixodes) on A. semotus. Of the 235 rodents that we examined for ticks, we documented 23 cases of infection and all of them occurred in the winter between December and February (PLS, unpublished results). Although tick infection appeared to be rare $(10 \%)$ and cannot be subjected to further quantitative analysis, it suggests that winter months at this study site may provide favorable conditions for ectoparasites with non-parasitic life stages. Therefore, it is important to study the life cycles of parasites in the wild before we can fully understand host-parasite dynamics.

\section{Conclusions}

In this study, we showed that mite parasitism in a rodent host was associated with reduced host reproduction and survival, with implications in the regulation of host 
populations and evolution of host life history. Our study is one of the few empirical studies of host-parasite ecology from a subtropical region where climate conditions are favorable for many parasites to persist at high abundance. Such empirical evidence adds valuable information to our overall understanding of the general rules governing host-parasite dynamics.

\section{Additional file}

Additional file 1: Figure S1. Estimation of Trombiculid mite abundance on their mouse host Apodemus semotus. (a) The larvae of Trombiculid mites (the white spots) attached themselves to the ear of an mouse. Based on the 2012 survey (June to September, 2012) where a total of 32 adult $A$. semotus were placed under anesthesia for a complete count of the number of mites attached to their ear and genital regions, (b) the mite count positively correlates with mite abundance index (the index has four abundance levels: $0=$ zero mite, $1=1$ to 9 mites, $2=10$ to 19 mites, $3=20$ mites or more). (c) The frequency distribution of the mite counts from the 2012 survey indicates $91 \%$ (29 out of 32) of the mice had a mite count between 0 and $29(0,1$ to 9, 10 to 19, 20 to 29), suggesting the mite abundance index captured most of the variation in mite count. Table S1. The generalized linear mixed model of Apodemus semotus reproduction as a function of sex and age.

\section{Competing interests}

The authors declare that they have no competing interests.

\section{Authors' contributions}

JWL and PLS designed the study, performed the statistical analyses, and wrote the manuscript. HCW developed the parasite protocols. HYL and PLS performed the field work. HYL and HCW analyzed the specimen. All authors participated in revising the manuscript. All authors read and approved the final manuscript.

\section{Acknowledgments}

We thank Si-Min Lin and Chi-Chien Kuo for insightful discussions on parasite ecology that inspired current study; Linghua Ke and Cong-Kun Zhou for their assistance in field work; and the Shei-Pa National Park for providing logistic support. This work was funded by the National Science Council in Taiwan (NSC 99-2621-B-003-001 and NSC 100-2621-B-003-006).

\section{Author details}

'Department of Life Science, National Taiwan Normal University, No. 88, Sec. 4, Tingzhou Rd, Taipei 11677, Taiwan. ${ }^{2}$ Centers for Disease Control, No.6, Linsen S. Rd, Taipei 10050, Taiwan.

\section{Received: 23 May 2014 Accepted: 21 November 2014}

\section{0.}

\section{References}

Albon SD, Stien A, Irvine RJ, Langvatn R, Ropstad E, Halvorsen O (2002) The role of parasites in the dynamics of a reindeer population. Proc $R$ Soc B-Biological Sci 269:1625-1632, doi:10.1098/rspb.2002.2064

Baker EW, Evans TM, Gould DJ, Hull WB, Keegan HL (1956) A manual of parasitic mites of medical or economic importance. National Pest Control Association, New York, USA

Bordes F, Ponlet N, de Bellocq JG, Ribas A, Krasnov BR, Morand S (2012) Is there sex-biased resistance and tolerance in Mediterranean wood mouse (Apodemus sylvaticus) populations facing multiple helminth infections? Oecologia 170:123-135, DOI:10.1007/s00442-012-2300-5

Brown ED, Macdonald DW, Tew TE, Todd LA (1994) Rhythmicity of eggs production by Heligmosomoides polygyrus in wood mice, Apodemus sylvaticus. J Helminthol 68:105-108, DOl:10.1017/S0022149X00013602

Buckling A, Rainey PB (2002) The role of parasites in sympatric and allopatric host diversification. Nature 420:496-499, DOl:10.1038/nature01164
Burns CE, Goodwin BJ, Ostfeld RS (2005) A prescription for longer life? Bot fly parasitism of the white-footed mouse. Ecology 86:753-761, DOl:10.1890/03-0735

Chadwick W, Little TJ (2005) A parasite-mediated life-history shift in Daphnia magna. Proc R Soc B-Biological Sci 272:505-509, DOl:10.1098/rspb.2004.2959

Christe P, Glaizot O, Evanno G, Bruyndonckx N, Devevey G, Yannic G, Patthey P. Maeder A, Vogel P, Arlettaz R (2007) Host sex and ectoparasites choice: preference for, and higher survival on female hosts. J Anim Ecol 76:703-710, DOl:10.1111/j.1365-2656.2007.01255.x

Corbet GB (1978) The mammals of the Palaearctic region: a taxonomic review. British Museum (Natural History), London, UK

Corbet GB, Hill JE (1992) The mammals of the Indomalayan region: a systematic review. Oxford University Press, London, UK

Cox RM, John-Alder HB (2007) Increased mite parasitism as a cost of testosterone in male striped plateau lizards Sceloporus virgatus. Funct Ecol 21:327-334, DOI:10.1111/j.1365-2435.2007.01251.x

de Bellocq JG, Krasnov BR, Khokhlova IS, Pinshow B (2006) Temporal dynamics of a T-cell mediated immune response in desert rodents. Comp Biochem Physiol A Mol Integr Physiol 145:554-559, DOl:10.1016/j.cbpa.2006.08.045

Dietsch TV (2005) Seasonal variation of infestation by ectoparasitic chigger mite larvae (Acarina: Trombiculidae) on resident and migratory birds in coffee agroecosystems of Chiapas, Mexico. J Parasitol 91:1294-1303, DOl:10.1645/ GE-558R.1

Gooderham K, Schulte-Hostedde A (2011) Macroparasitism influences reproductive success in red squirrels (Tamiasciurus hudsonicus). Behav Ecol 22:1195-1200, DOl:10.1093/beheco/arr112

Goodman BA, Johnson RTJ (2011) Ecomorphology and disease: cryptic effects of parasitism on host habitat use, thermoregulation, and predator avoidance. Ecology 92:542-548, DOI:10.1890/10-0516.1

Hakkarainen H, Huhta E, Koskela E, Mappes T, Soveri T, Suorsa P (2007) Eimeria-parasites are associated with a lowered mother's and offspring's body condition in island and mainland populations of the bank vole. Parasitology 134:23-31, DOI:10.1017/S0031182006001120

Hamilton WD, Zuk M (1982) Heritable true fitness and bright birds: a role for parasites? Science 218:384-387, DOI:10.1126/science.7123238

Hurd H (2001) Host fecundity reduction: a strategy for damage limitation? Trends Parasitol 17:363-368, DOl:10.1016/S1471-4922(01)01927-4

Kallio ER, Voutilainen L, Vapalahti O, Vaheri A, Henttonen H, Koskela E, Mappes T (2007) Endemic hantavirus infection impairs the winter survival of its rodent host. Ecology 88:1911-1916, DOI:10.1890/06-1620.1

Khokhlova IS, Spinu M, Krasnov BR, Degen AA (2004) Immune responses to fleas in two rodent species differing in natural prevalence of infestation and diversity of flea assemblages. Parasitol Res 94:304-311, DOl:10.1007/s00436004-1215-4

Klein SL (2004) Hormonal and immunological mechanisms mediating sex differences in parasite infection. Parasite Immunol 26:247-264, DOl:10.1111/j.0141-9838.2004.00710.x

Klein LK, Roberts CW (2010) Sex hormones and immunity to infection. Springer Verlag, Berlin, Heidelberg

Klukowski M (2004) Seasonal changes in abundance of host-seeking chiggers (Acari: Trombiculidae) and infestations on fence lizards, Sceloporus undulatus. J Herpetol 38:141-144, DOl:10.1670/127-03N

Krasnov BR, Morand S, Hawlena H, Khokhlova IS, Shenbrot Gl (2005) Sex-biased parasitism, seasonality and sexual size dimorphism in desert rodents. Oecologia 146:209-217, DOl:10.1007/s00442-005-0189-y

Krasnov BR, Bordes F, Khokhlova IS, Morand S (2012) Gender-biased parasitism in small mammals: patterns, mechanisms, consequences. Mammalia 76:1-13, DOl:10.1515/mammalia-2011-0108

Kuo CC, Wang HC, Huang CL (2011) Variation within and among host species in engorgement of larval trombiculid mites. Parasitology 138:344-353, DOl:10.1017/S003118201000140X

Lemaitre J, Fortin D, Montiglio PO, Darveau M (2009) Bot fly parasitism of the red-backed vole: host survival, infection risk, and population growth. Oecologia 159:283-294, DOl:10.1007/s00442-008-1219-3

Lin LK, Shiraishi S (1992a) Home range and microhabitat utilization in the Formosan wood mouse, Apodemus semotus. J Faculty Agri Kyushu Univ 37:13-27

Lin LK, Shiraishi S (1992b) Reproductive biology of the Formosan wood mouse, Apodemus semotus. J Faculty Agri Kyushu Univ 36:183-200

Lochmiller RL, Deerenberg C (2000) Trade-offs in evolutionary immunology: just what is the cost of immunity? Oikos 88:87-98, DOl:10.1034/j.16000706.2000.880110.x 
Martin LB, Weil ZM, Nelson RJ (2008) Seasonal changes in vertebrate immune activity: mediation by physiological trade-offs. Philo Transac Royal Soc B: Biol Sci 363:321-339

May RM, Anderson RM (1979) Population biology of infectious diseases: part II. Nature 280:455-461, DOl:10.1038/280455a0

Merino S, Potti J (1995) Mites and botflies decrease growth and survival in nestling pied flycatchers. Oikos 73:95-103, DOl:10.2307/3545730

Møller AP, Arriero E, Lobato E, Merino S (2009) A meta-analysis of parasite virulence in nestling birds. Biol Rev 84:567-588, DOl:10.1111/j.1469-185X.2009.00087.X

Moore SL, Wilson K (2002) Parasites as a viability cost of sexual selection in natural populations of mammals. Science 297:2015-2018, DOl:10.1126/ science.1074196

Morales-Montor J, Chavarria A, De León MA, Del Castillo LI, Escobedo EG, Sánchez EN, Varqas JA, Hernández-Flores M, Romo-González T, Larralde C (2004) Host gender in parasitic infections of mammals: an evaluation of the female host supremacy paradigm. J Parasitol 90:531-546, DOI:10.1645/GE-113R3

Morand S, De Bellocq JG, Stanko M, Miklisova D (2004) Is sex-biased ectoparasitism related to sexual size dimorphism in small mammals of Central Europe? Parasitology 129:505-510, DOI:10.1017/S0031182004005840

Nelson WA, Keirans JE, Bell JF, Clifford CM (1975) Host-ectoparasite relationships. J Med Entomol 12:143-166

Neuhaus P (2003) Parasite removal and its impacts on litter size and body condition in Columbian ground squirrels (Spermophilus columbianus). Proc R Soc B-Biological Sci 270:S213-S215, DOl:10.1098/rsbl.2003.0073

Patterson JE, Neuhaus P, Kutz SJ, Ruckstuhl KE (2013) Parasite removal improves reproductive success of female North American red squirrels (Tamiasciurus hudsonicus). PLoS One 8:e55779, DOl:10.1371/journal.pone.0055779

Poulin R (1996) Sexual inequalities in helminth infections: a cost of being a male? Am Nat 147:287-295, DOl:10.1086/285851

Redpath SM, Mougeot F, Leckie FM, Elston DA, Hudson PJ (2006) Testing the role of parasites in driving the cyclic population dynamics of a gamebird. Ecol Lett 9:410-418, DOl:10.1111/j.1461-0248.2006.00895.x

Ree HI, Lee IY, Cho MK (1992) Study on vector mites of tsutsugamushi disease in Cheju Island, Korea. Korean J Parasitol 30:341-348

Robar N, Burness G, Murray DL (2010) Tropics, trophics and taxonomy: the determinants of parasite-associated host mortality. Oikos 119:1273-1280, DOI:10.1111/j.1600-0706.2009.18292.x

Sanchez A, Devevey G, Bize P (2011) Female-biased infection and transmission of the gastrointestinal nematode Trichuris arvicolae infecting the common vole, Microtus arvalis. Int J Parasitol 41:1397-1402, DOl:10.1016/j.ijpara.2011.09.004

Schalk G, Forbes MR (1997) Male biases in parasitism of mammals: effects of study type, host age, and parasite taxon. Oikos 78:67-74, DOl:10.2307/3545801

Schall JJ (1983) Lizard malaria: cost to vertebrate host's reproductive success. Parasitology 87:1-6, DOl:10.1017/S0031182000052367

Schall JJ, Dearing MD (1987) Malarial parasitism and male competition for mates in the western fence lizard, Sceloporus occidentalis. Oecologia 73:389-392, DOI:10.1007/BF00385255

Schall JJ, Houle PR (1992) Malarial parasitism and home range and social status of male western fence lizards, Sceloporus occidentalis. J Herpetol 26:74-76, DOl:10.2307/1565026

Schall JJ, Bennett AF, Putnam RW (1982) Lizards infected with malaria: physiological and behavioral consequences. Science 217:1057-1059, DOl:10.1126/science.7112113

Schwanz LE (2008) Chronic parasitic infection alters reproductive output in deer mice. Behav Ecol Sociobiol 62:1351-1358, DOl:10.1007/s00265-008-0563-y

Shaner PL, Wu SH, Ke L, Kao SJ (2013) Trophic niche divergence reduces surviva in an omnivorous rodent. Evol Ecol Res 15:1-14

Shatrov AB, Kudryashova NI (2006) Taxonomy, life cycles and the origin of parasitism in trombiculid mites. In: Morand S, Krasnov BR, Poulin R (eds) Micromammals and Macroparasites. Springer, Tokyo, Japan

Sheldon BC, Verhulst S (1996) Ecological immunology: costly parasite defences and trade-offs in evolutionary ecology. Trends Ecol Evol 11:317-321, DOl:10.1016/0169-5347(96)10039-2

Shields JD, Wood EEI (1993) Impact of parasites on the reproduction and fecundity of the blue sand crab Portunus pelagicus from Moreton Bay, Australia. Mar Ecol Prog Ser 92:159-170, DOl:10.3354/meps092159

Simon A, Thomas D, Blondel J, Perret P, Lambrechts MM (2004) Physiological ecology of Mediterranean blue tits (Parus caeruleus L.): effects of ectoparasites (Protocalliphora spp.) and food abundance on metabolic capacity of nestlings. Physiol Biochem Zool 77:492-501, DOI:10.1086/383512
Skarstein F, Folstad I, Liljedal S (2001) Whether to reproduce or not: immune suppression and costs of parasites during reproduction in the Arctic charr Can J Zool 79:271-278, DOl:10.1139/cjz-79-2-271

Stien A, Irvine RJ, Ropstad E, Halvorsen O, Langvatn R, Albon SD (2002) The impact of gastrointestinal nematodes on wild reindeer: experimental and cross-sectional studies. J Anim Ecol 71:937-945, DOl:10.1046/j.13652656.2002.00659.x

Takahashi M, Machida K, Murata M, Misumi H, Hori E, Kawamura A, Tanaka H (1993) Seasonal development of Leptotrombidium pallidum (Acari: Trombiculidae) observed by experimental rearing in the natural environment. J Med Entomol 30:320-325

Traub R, Wisseman CL Jr (1968) Ecological considerations in scrub typhus: 2. Vector species. Bull World Health Organ 39:219

Turner WC, Versfeld WD, Kilian JW, Getz WM (2012) Synergistic effects of seasonal rainfall, parasites and demography on fluctuations in springbok body condition. J Anim Ecol 81:58-69, DOl:10.1111/j.1365-2656.2011.01892.x

Vandegrift KJ, Raffel TR, Hudson PJ (2008) Parasites prevent summer breeding in white-footed mice, Peromyscus leucopus. Ecology 89:2251-2258, DOl:10.1890/ 07-1935.1

Waller PJ (1997) Nematode parasite control of livestock in the tropics/subtropics: the need for novel approaches. Int J Parasitol 27:1193-1201, DOl:10.1016/ S0020-7519(97)00117-3

Waterman JM, Macklin GF, Enright C (2014) Sex-biased parasitism in Richardson's ground squirrels (Urocitellus richardsonii) depends on the parasite examined. Can J Zool 92:73-79, DOl:10.1139/cjz-2013-0151

Wharton GW, Fuller HS (1952) A manual of the chiggers. The biology, classification, distribution, and importance to Man of the larvae of the family Trombiculidae (Acarina). Memoirs Entomol Soc Washington 4:1-185

White GC, Burnham KP (1999) Program MARK: survival estimation from populations of marked animals. Bird Study 46:120-138

Xing-Yuan M, Xian-Guo G, Wen-Ge D, Ai-Qin N, Ti-Jun Q, Dian W (2007) Ectoparasites of Chevrier's field mouse, Apodemus chevrieri, in a focus of plague in southwest China. Med Vet Entomol 21:297-300

Zohar S, Holmes JC (1998) Pairing success of male Gammarus lacustris infected by two acanthocephalans: a comparative study. Behav Ecol 9:206-211, DOI:10.1093/beheco/9.2.206

Zuk M, McKean KA (1996) Sex differences in parasite infections: patterns and processes. Int J Parasitol 26:1009-1024, DOl:10.1016/S0020-7519(96)80001-4

doi:10.1186/s40555-014-0079-2

Cite this article as: Lin et al:: The effects of mite parasitism on the reproduction and survival of the Taiwan field mice (Apodemus semotus). Zoological Studies 2014 53:79.

\section{Submit your manuscript to a SpringerOpen ${ }^{\odot}$ journal and benefit from:}

- Convenient online submission

Rigorous peer review

- Immediate publication on acceptance

- Open access: articles freely available online

- High visibility within the field

- Retaining the copyright to your article

Submit your next manuscript at $>$ springeropen.com 